\title{
The Role of Faculty in Fund Raising at Black Colleges: What Is It and What Can It Become?
}

Received (in revised form): November 15, 2004

\section{Marybeth Gasman}

Marybeth Gasman is an assistant professor in the Graduate School of Education at the University of Pennsylvania. Her most recent books include Charles S. Johnson: Leadership Behind the Veil in the Age of Jim Crow (with Patrick J. Gilpin) and Fundraising from Black College Alumni: Successful Strategies for Supporting Alma Mater (with Sibby Anderson-Thompkins). Her work focuses on issues of fund raising and philanthropy in the African American community and is primarily historical in nature. She is currently working on a history of the United Negro College Fund.

\section{Abstract \\ This article explores the role of faculty in fund raising at black colleges, asking what it has been and what it can become. In addition to an historical exploration of this role, the author draws upon qualitative interviews with both faculty and administrators to make recommendations for future faculty roles.}

\section{Keywords:}

African American, faculty, black colleges, bistory

\section{Introduction}

In 1946, W. E. B. Du Bois, who had been a faculty member at several black colleges said, "Education is not and should not be a private philanthropy: it is a public

Author's Contact Address:

Marybeth Gasman

University of Pennsylvania

Graduate School of Education

Higher Education Division

3700 Walnut Street, Room 423A

Philadelphia, PA 19104-6216

USA

Phone: + 12155733990

Email: mgasman@gse.upenn.edu service and whenever it becomes a gift of the rich it is in danger." A little over ten years later, Du Bois reiterated his point of view in a letter to historian Merle Curti:

During my whole career, I have tried not to be put in a position where collecting money from philanthropists would be any considerable part of my work. For that reason I have always declined to [be a] candidate for the presidency of any college or organization where I had to raise funds. Philanthropy is being guided by Big Business to ward off Socialism and Communism, to control labor unions, and to curb all sorts of "radical" thought. $^{2}$

Although I study fundraising at black colleges and I am a faculty member; up until recently, I rarely thought about the role that professors play in the acquisition of institutional funds. After conducting interviews with several vice presidents of advancement at black colleges, it appears that this topic has not been widely discussed. 
Rereading Du Bois's words prompted me to think about the role of faculty in fund raising at historically black colleges. Why did he avoid this role? Who protects the academy from the "dangers" of private philanthropy? Is that the job of the faculty? My goal for this paper is to spur such a discussion. In order to do so, I will first provide a brief history of the role of faculty at black colleges in the area of fund raising. Next, I will describe the role of faculty today. Finally, but most importantly, I will address the role that faculty members could have in fund raising.

In preparation for this article, I conducted interviews with 40 individuals for this study. Ten interviewees are vice presidents of institutional advancement (three at public black colleges, seven at private black colleges); ten interviewees are directors of alumni relations (two at public black colleges, eight at private black colleges); eight interviewees are faculty (four at public black colleges, four at private black colleges); and 32 interviewees are alumni of black colleges (17 graduated from private black colleges, ten from public black colleges, and five were graduates of both public and private black colleges). Interviews were 35 minutes to one hour in length. A set of ten openended questions and asked of each participant and time was allotted for open commentary at the end of each interview. Participants asked to remain anonymous. Interview data was analyzed and common themes were pulled from the data. The organization of this paper and the recommendations are based on these themes.

\section{History of Faculty Role in Fund Raising in Black Colleges}

In the post-Civil War period, newly created black colleges, whether founded by
African American or white missionaries were in great need of funding and, in many cases, at the mercy of the wealthy for survival. ${ }^{3}$ These institutions often took donations from whoever was willing to give. As the United States moved into the industrial age, and the industrialists of the time needed trained workers, donations to black colleges began to come with attached strings. ${ }^{4}$ Philanthropy became a mechanism for power and control over the college curriculum. ${ }^{5}$ Although many of the black college presidents at the time had to be pragmatic in their approach to fund raising, black college faculty were not always happy with the control imposed by these "benevolent" industrialists. For African Americans, a liberal arts education was, for the most part, thought of as frivolous by the industrialists and southern whites. According to historian James D. Anderson, faculty, alumni, and students came together to chastise their white presidents and boards of trustees for compromising the depth and rigor of the curriculum in order to train workers for northern industry's southern enterprises. ${ }^{6}$ Major uprisings occurred at several institutions, including Hampton and Fisk. ${ }^{7}$ In these instances, faculty did play a role in fund raising-by acting as a check on the actions of the institution. Do faculty members play this same role today? Do they know what kinds of arrangements are made in order to secure funds? Should they know?

In the past, some faculty played a role in institutional fund raising that was quite literally "hands on." At Fisk University, for example, George L. White created and traveled with the famed Jubilee Singers in the 1870 s. $^{8}$ They raised enough money to build Jubilee Hall, which still stands today as a monument to black self-help on the Fisk University campus. Of course, 
Hampton and other black colleges followed suit and created their own singing/fund-raising groups. Fisk's Jubilee Singers were an integral part of campus fund raising-in fact, when other sources had dried up, then president Adam K. Spence would send the singers out into the world to sing in order to sustain the operating budget.' George L. White's use of the Jubilee Singers is just one example of the innovative ways that faculty at black colleges, in an effort to secure their jobs and the viability of their institutions, participated in the fund-raising process. Are current faculty members as involved in the creation of innovative ways to raise funds? Do they think about their role in guaranteeing the future of their institutions? Should they play a role? What ethical dilemmas might they face in playing such a role?

If faculty members are "on the road" fund raising, their teaching may suffer and students may come to resent their absence. We find an example of this problem in the experience of Fisk University sociologist Charles S. Johnson. In the 1940s, under the presidency of Thomas E. Jones, Johnson became very involved in raising funds from northern philanthropists. Although his ability to persuade the donors was unmatched, his teaching and management of the department of social sciences often suffered. ${ }^{10}$ Students complained about "boring, scattered lectures" and the staff grumbled about "a lack of direction" in the department (from interviews with Leslie M. Collins, May 15, 1999; Mary Thompson to author, March 28, 1999; Gladys Forde, March 27, 1999) More often than not, these complaints were followed by comments about Johnson's frequent absences from campus. Although it is helpful for faculty to assist with fund raising, is it practical given the mission of the college?
Another common problem in fund raising is the portrayal of the institution to the public. The famed, although often misunderstood, "debate" between Booker T. Washington and W. E. B. Du Bois provides an example of this. While this disagreement was primarily about curriculum and outside control, it was also about language-the language used to secure funds. According to Du Bois, the words used by Washington to describe Tuskegee Institute and the students who attended it were meant to appease white philanthropists and portray black students as mere "industrious laborers." current institutions representing their programs and students-do they cast themselves in the best possible light? When is it necessary for faculty members to be critical of fund-raising campaigns that misrepresent students and academic programs?

Mary McLeod Bethune, the founder and president of what became BethuneCookman College, used her faculty to bolster the college's fund-raising efforts during its early years (at the time, the institution was called the Daytona Literary and Industrial School for Training Negro Girls). Faculty members would often go door to door asking for any kind of support-monetary or inkind. ${ }^{12}$ Do faculty members today encourage people to support their institutions? Do they discuss, proclaim, and "sell" the merits of their institutions? Should they, or is this the job of the president, trustees, and advancement staff only? Does "promoting" or "selling" the institution conflict with the teaching and research mission of faculty members? In recent years, there has been pressure to make educational institutions function more like corporations-which are driven by sales. An emphasis on selling colleges and universities as products could lead to 
a cheapening of their institutional missions and the quality of their curriculum.

\section{The Role of Faculty Today}

What then, is the role of black college faculty in fund raising today? The available literature pertains, for the most part, to faculty in the predominantly white setting and focuses on training faculty members to ask alumni and corporations for funds. ${ }^{13}$ Therefore, in an effort to gather new information, I interviewed vice presidents of advancement, development officers, alumni directors, faculty, and students at black colleges about this role. Although these development professionals told me that there was no official role for faculty they could identify a few things that professors do in support of fund raising.

One of the most common jobs that faculty members did was to identify potential fund-raising sources for the college. This is, of course, consistent with the literature. Whereas development officers may know how to raise funds, they may not be familiar with the intricacies of an academic field. Faculty members, on the other hand, have what one development officer calls a "fire within for the topic." A professor who knows the corporate, foundation, and individual supporters in his or her field can make introductions and provide research for grant proposals. Faculty members are sometimes asked to speak at donor dinners or special events, and their names can be a draw to some potential donors who have very specific interests. For example, an expert on Langston Hughes may draw fans of Hughes's poetry.

For some faculty members the involvement in fund raising begins when they take on an administrative role. For example, academic deans typically come from the faculty ranks and often represent the faculty point of view when sitting on advancement committees. Many times they help identify funding sources specific to their college or discipline. One way for faculty to have influence in the fundraising process is by maintaining a close relationship with their academic dean.

In some cases, development professionals reported that faculty members play a disruptive rather than helpful role in the fund-raising process. This was particularly the case in regard to what development staff termed "nuisance money." Nuisance money may refer to grants of less than $\$ 5000$ that come with an inordinate amount of paperwork; it may also mean the habit of asking foundations, individuals, and corporations for small donations when the university could be asking for large amounts of money (definitions are based on interviews with advancement personnel). From the information gathered in my interviews, it seems that these problems are quite common at black colleges. One reason for this may be that, up until recently, many black colleges lacked advancement professionals on their campuses. Faculty members had basically been left to fend for themselves and that meant finding funds to support their programs in any way possible.

The last, but perhaps most important, faculty role stems from their teaching. Black college development staff and alumni both reported that faculty members have stronger relationships with former students than almost anyone at a college. Specifically, when former students come back to campus-who do they visit? Not the development staff-but their favorite faculty members. This relationship continues for many years, but has rarely been used for fund raising. 
Could faculty make use of their special relationships with former students? Should they? If they take on this role, how do faculty members balance time spent maintaining relationships with students with their teaching and scholarship requirements?

\section{What could Be the Role of Faculty?}

Clearly there are some faculty members who, put off by the potential ethical dilemmas, do not want any role for themselves in fund raising. This leads me to the heart of this article-what could the role of faculty be in fund raising? Based upon my research and the interviews that I conducted, I offer the following suggestions.

If they are to play any role at all, faculty members need to understand the process of fund raising-not just writing grant proposals and soliciting funds for pet projects. They need to understand the role of philanthropy in society at large and its place among the multiple funding sources of public and private institutions. Further, faculty members should be aware of the ethical issues surrounding the use of capital to support education. One approach to learning more is to tap the resources at their own institutionsspecifically, colleagues who do research on philanthropy. Experts can be found in education, business, public policy, nonprofit management, history, and so forth. Numerous texts are also available on the subject-ranging from the theoretical to the practical. For example, Dwight Burlingame at Indiana University has edited an excellent volume entitled, Critical Issues in Fundraising. ${ }^{14}$ This text not only offers practical information on fund raising, including minority fund raising, but also provides a theoretical foundation. Burlingame and his colleagues ask us to question the entire idea of fund raising. They raise some difficult issues in the book, including the fears of minority groups (specifically indigenous cultures) that giving is a means for domination. The book ultimately endorses fund raising, but is sensitive to the issues of power and control inherent in philanthropy. Regarding African American fund raising in particular, I would like to see academic programs that speak to the specific concerns of black giving and the ethics of fund raising within the black college setting. I would also like to see a black college take the lead and develop courses-perhaps a master's program in black or minority philanthropy. Currently, courses for future development staff are taught using a "white framework" in predominantly white settings.

One area in which faculty members can help without straying from their traditional roles is to act as a connection point between fund-raising staff and alumni. In this regard, it may be possible to encourage giving without actively soliciting contributions. For a professor who has acted as a mentor-a person who has helped students to make life-changing decisions-simply taking an interest in students after they graduate may steer them toward giving. This type of influence is all the more potent at black colleges where there is not only a student/ faculty bond but a bond to the black community. Research shows that African American giving is based on trust, knowledge of an institution, and personal connections and relationships. ${ }^{15}$ And, at a black college where both student and professor are likely to be African American these factors are all present.

Regarding the question of how institutions represent themselves to potential funders, much can be learned 
from the study of historical fund-raising rhetoric. In my own research, I have looked at the work of the fund-raising firm Marts and Lundy, Inc. at Fisk University and the philanthropist John D. Rockefeller, Jr's efforts on behalf of the United Negro College Fund (UNCF). These examples show that fund raisers tell donors what they want to hear. It was by making the pitch in words that were familiar to the donor that someone like John D. Rockefeller, Jr. could convince just about anyone to give money to the UNCF during the racially tense 1940s and 1950s. When asking industry leaders for money, the UNCF was "preparing a skilled and educated workforce;" when Rockefeller was talking to southern whites, the UNCF was "another example of the Rockefeller family's support of solutions to the race problem that engage the southern way;" when trying to convince northern liberals, the UNCF was "progressive and open-minded." Archive files on the United Negro College fund contain hundreds of letters which include examples of this kind of fund-raising rhetoric. $^{16}$

What role do faculty members have in making sure that their institutions are represented in a way that is consistent with their educational mission? By serving on advancement committees, faculty members could have a say in the design of fund-raising campaigns. This will take flexibility on the part of faculty-they need to understand the importance of development work and what advancement professionals have to offer. And advancement professionals will need to be open to the contributions of faculty as well.

Just as in the historical examples at Fisk and Hampton, in which faculty rebuked the administration for its indulgent attitude toward the influence of donors, faculty today need to be critical of the relationships between the university and the donor. This may be one way to ensure that donors do not cause the institutional mission to drift. In this way faculty can help maintain equilibrium between the different forces at work within our institutions.

Many who object to any faculty role in fund raising do so on the grounds that the university should not be a business and that the teaching and research mission should not be mixed up with money. However, I argue that it is precisely to avoid such unholy alliances that faculty must become involved. In the grand tradition of the academy-for example, Oxford and Cambridge, the faculty member is a governor of the institution. Administrators are available to ensure that the institution runs smoothly and to do the things that faculty members are not particularly good at, but they ultimately share power with faculty members. To hold on to this power faculty members must be willing to participate in all aspects of governanceincluding fund raising. Acting as the informed critic, but not just being critical, is perhaps the greatest role faculty can play in fund raising.

\section{References}

1. W. E. B. Du Bois (1973), "The future and function of the private negro college," in Herbert Aptheker (Ed.), The Education of Black People, Ten Critiques, 1906-1960, Monthly Review Press, New York, p. 142.

2. W. E. B. Du Bois (1976), Letter to Professor Merle Curti, 4 June 1958, in Herbert Aptheker (Ed.), The Correspondence of W. E. B. Du Bois. Volume III Selections, 1944-1963, University of Massachusetts Press, Amherst, p. 430.

3. J. D. Anderson (1988), The Education of Blacks in the South, 1860-1935, University of North Carolina Press, Chapel Hill.

4. Ibid.

5. E. Berman (1983), The Influence of the Carnegie, Ford, and Rockefeller Foundations on American Foreign Policy: 
The Ideology of Philanthropy, State University of New York Press, New York.

6. Anderson (1988), The Education of Blacks, op. cit.; S. Peeps (1981), "Northern philanthropy and the emergence of black higher education-do-gooders, compromisers, or co-conspirators?" Journal of Negro Education, 50, 3, pp. 251-69; Berman (1983), The Influence of the Carnegie, Ford, and Rockefeller Foundations, op. cit.

7. R. Wolters (1975), The New Negro on Campus. Black College Rebellions of the 1920s, Princeton University Press, Princeton, NJ.

8. J. Richardson (1980), A History of Fisk University, 1865-1946, University of Alabama Press, Tuscaloosa.

9. T. Anderson (1997), "The Fisk Jubilee Singers: Performing ambassadors for the survival of an American treasure, 1871-1878," Ph.D. diss., Georgia State University; A. Ward (2000), Dark Midnight When I Rise: The Story of the Jubilee Singers, who Introduced the World to the Music of Black America, Farrar, Straus, and Giroux, New York; G. D. Pike (1873), Jubilee Singers, and Their Campaign for Twenty Thousand Dollars, Hodder and Stoughton, London.
10. P. J. Gilpin and M. Gasman (2003), Charles $S$. Johnson. Leadership Behind the Veil in the Age of Jim Crow, SUNY Press, Albany, NY.

11. W. E. B. Du Bois (1995), The Souls of Black Folks, Signet Classic, New York; D. Levering Lewis (1993), W.E.B. Du Bois. Biography of a Race, Henry Holt, New York.

12. E. M. Smith, (1996), "Mary McLeod Bethune's 'Last Will and Testament': A legacy for race vindication," Journal of Negro History, 81, Winter, pp. 105-22.

13. J. Leed (1987), "Beyond the ask: Ten other ways to involve faculty in fund raising," CASE Currents, March 1987; Kay Murphy, "Multiply and be fruitful: Making the most of deans and faculty in development," CASE Currents, September, 1993.

14. D. Burlingame (1997), Critical Issues in Fundraising, John Wiley \& Sons, New York.

15. M. Gasman and S. Anderson-Thompkins (2003), Fundraising from Black College Alumni? Successful Strategies for Supporting Alma Mater, CASE Books, Washington, DC.

16. J. D. Rockefeller, Jr. Papers, Rockefeller Archive Center, Sleepy Hollow, New York.

\section{Practitioner's Perspective}

I'm pleased to have been asked to comment on Dr. Marybeth Gasman's solid and insightful paper. I'd like to emphasize and expand on a number of points she's made, from my perspective as a fund-raising and development practitioner at HBCUs, first as Vice President for Institutional Advancement at Dillard University in New Orleans, and now as Executive Vice President of the United Negro College Fund.

First, I want to subscribe unreservedly to what I take to be the organizing idea in Dr. Gasman's paper, her observation that "faculty members must be willing to participate in ... fund raising." From the practitioner's point of view, the first challenge that raises is convincing faculty of the importance of their participation. I understand that many dedicated teachers and scholars like our HBCU faculty members see fund raising as, at best, someone else's job, the job of people who know how to do it, development professionals. At worst they may see it as the contaminated confluence of commerce and scholarship, believing, as Dr. Gasman puts it, that "the teaching and research mission should not be mixed up with money."

This is an opportunity, it seems to me, for HBCU development professionals to teach the teachers: to help them understand that the financial viability of a college, which means the financial viability of its mission, is everybody's job, everybody's cause. Everybody has their part to play. It would be wonderful if we lived in a world in which financial support for worthy causes like educating and nurturing the next generation materialized unbidden. But that's not the world we live in. To paraphrase A. Philip Randolph, there are no reserved funds. You get what you can raise. If you don't raise anything, you won't get anything. So it behooves all of us to be willing to play our parts, to do what we can to help our HBCUs not only survive, but prosper.

In that connection, there's what in New Orleans they call a lagniappe, something extra, that faculty derive from participating in development. And that is, as 
Dr. Gasman points out, the opportunity to make sure that the college or university stays true to its mission and its vision. Fund raising has to be driven by vision. We're not raising funds just for the sake of increasing our bank balance. We're raising funds that make it possible to offer a unique education to young people who need it, who deserve it, and who won't get it without us. Our faculty is the keeper of that flame, and we need them to keep it burning and keep it bright.

This leads me to something I feel very strongly about, an issue that Dr. Gasman mentions and I'd like to expand on. Dr. Gasman mentions the problem of "nuisance money," grants that address a professor's personal research interests, but are too small for the university to administer efficiently. Related to the nuisance money issue is finding the proper balance between a faculty member's specialized research and the broad, common good of the college and the educational and cultural community that gathers under the shelter of its umbrella. Don't get me wrong. Research is important, and it's good that it's done at HBCUs. But professors also need to play a role as members of the larger college community, the community of teachers and students and learning that is the college's core mission. Because if that community falters or fails-and we need only read the headlines to be reminded that it can falter and can fail-then everything else that happens at the college, including research, becomes impossible.

So to sum this point up, development professionals at HBCUs need to help faculty members understand that their participation in development activities has to be in support of the greater good of the college and the mission.

I think there are also a couple of things development professionals need to understand. The most vital is that faculty members are not only important to development, they're absolutely central to it, and whatever effort is required to include them is well worth it. It's their teaching and research, after all, that funds are being raised to support, directly or indirectly. Even funds raised for projects like gyms or parking garages are needed because students have enrolled to take classes from professors.

The faculty's centrality to what the university does makes them central to the fundraising process. Funders, especially first-time funders, want to meet and talk to the people whose activities they'll be funding, and at a university, that means professors. A funder is investing in our ability to educate, and that ability is absolutely tied to the experience and talent of our teachers. A savvy, articulate, and well-prepared development professional can open doors and set the stage. But the presence-at the right time, and I'll talk more about that in a moment-of a dedicated and inspirational teacher can be a vivid illustration that the fine goals we have laid out can actually happen.

That may be particularly important for HBCUs. Their names and histories will be familiar to many prospective donors and underwriters. But there may be less familiarity with their modern roles and how their unique mission has evolved over the years. Donors may even conflate all HBCUs with the few whose tribulations they've read about. Having a professor there will thus be doubly important.

Integrating faculty members into fund-raising activities carries with it another obligation: to be smart about how and when you bring them into the process. I said before that everyone has their role to play. The role of faculty is not to become 
expert in development and fund raising. That's the development professional's role. The faculty's role is first to participate in the process early enough to make sure that the project is aligned with the college's mission and, if the project relates to a particular scholarly discipline, to make sure that it reflects the best scholarly and educational thinking. The faculty's second role is to serve as an exemplar of what's best and most vital about the college.

At which stages in the development process the faculty presence is most needed and most effective will vary with every project and every funder. But what's essential is to respect their time, and to make sure that fund-raising activities don't interfere with the essence of professors' contribution, their teaching-their presence in the classroom and their accessibility to students who need their help and advice.

Being smart about how you use faculty in fund raising is important to give the development effort the best chance of success, and to keep professors happy-and therefore available in the future. But we see an even more important reason in Dr. Gasman's reminder of the unhappiness of Fisk University students and colleagues in the 1940s at the frequent fund-raising-related absences of Charles S. Johnson. To the extent that we allow fund raising to interfere with teaching and scholarship, we may raise a few more dollars, but we undermine the vision and mission for which we're raising money in the first place.

John P. Donohue

Executive Vice President, United Negro College Fund, Fairfax, Virginia 